University of Wollongong

Research Online

Faculty of Law, Humanities and the Arts Papers (Archive)

Faculty of Arts, Social Sciences \& Humanities

2013

Moving beyond rights-based management: a transparent approach to distributing the conservation burden and benefit in tuna fisheries

Quentin A. Hanich

University of Wollongong, hanich@uow.edu.au

Yoshitaka Ota

Nereus Programme, Nippon/UBC, Vancouver

Follow this and additional works at: https://ro.uow.edu.au/lhapapers

Part of the Arts and Humanities Commons, and the Law Commons

Research Online is the open access institutional repository for the University of Wollongong. For further information contact the UOW Library: research-pubs@uow.edu.au 


\title{
Moving beyond rights-based management: a transparent approach to distributing the conservation burden and benefit in tuna fisheries
}

\author{
Abstract \\ Determining the distribution of the conservation burden and benefit is a critical challenge to the \\ conservation and management of trans-boundary fish stocks. Given current levels of overfishing and \\ overcapacity in many trans-boundary fisheries, some or all participating States must necessarily reach a \\ compromise with regard to their interests and carry some share of the conservation burden. This article \\ proposes a new approach to distributing the conservation burden and benefit in trans-boundary fisheries, \\ and explores this approach in the world's largest tuna fishery: the tropical tuna fisheries of the western \\ and central Pacific. Such an approach would enable Regional Fisheries Management Organizations \\ (RFMOs) to transparently ensure that conservation burden and benefit distributions are consistent with \\ international obligations. The article recommends that RFMOs consider developing decision-making \\ frameworks that would enable existing scientific processes to determine the necessary extent of \\ conservation measures, while a new conservation burden methodology would then determine the \\ implementation of the measure and its impact on each member.

\section{Keywords} \\ era2015 \\ Disciplines \\ Arts and Humanities | Law

\section{Publication Details} \\ Q. A. Hanich and Y. Ota, 'Moving beyond rights-based management: a transparent approach to distributing \\ the conservation burden and benefit in tuna fisheries' (2013) 28 (1) International Journal Of Marine And \\ Coastal Law 135-170.
}




\title{
Moving Beyond Rights-Based Management: A Transparent Approach to Distributing the Conservation Burden and Benefit in Tuna Fisheries
}

\author{
Quentin Hanich \\ Australian National Centre for Ocean Resources and Security, \\ University of Wollongong, Wollongong, NSW, Australia \\ Yoshitaka Ota* \\ Nereus Programme, Nippon/UBC, Vancouver, BC, Canada
}

\begin{abstract}
Determining the distribution of the conservation burden and benefit is a critical challenge to the conservation and management of trans-boundary fish stocks. Given current levels of overfishing and overcapacity in many trans-boundary fisheries, some or all participating States must necessarily reach a compromise with regard to their interests and carry some share of the conservation burden. This article proposes a new approach to distributing the conservation burden and benefit in trans-boundary fisheries, and explores this approach in the world's largest tuna fishery: the tropical tuna fisheries of the western and central Pacific. Such an approach would enable Regional Fisheries Management Organizations (RFMOs) to transparently ensure that conservation burden and benefit distributions are consistent with international obligations. The article recommends that RFMOs consider developing decision-making frameworks that would enable existing scientific processes to determine the necessary extent of conservation measures, while a new conservation burden methodology would then determine the implementation of the measure and its impact on each member.
\end{abstract}

\section{Keywords}

conservation burden and benefit; tuna; fisheries governance; western and central Pacific fisheries

\section{Introduction}

In 2012 the Food and Agriculture Organisation of the United Nations (FAO) reported that global marine catches were in decline, with increased percentages of global fish stocks identified as over-exploited. The FAO found that the

\footnotetext{
* This article was partially supported by the NF-UBC Nereus Program, a collaborating interdisciplinary initiative of The Nippon Foundation and six research institutions.
} 
state of world marine fisheries was worsening and this has had a negative impact on fisheries production. ${ }^{1}$ Concerned States have noted that current levels of fishing are unsustainable and "... leading inexorably to an impending crisis for global marine fisheries." ${ }^{2}$ This article builds on arguments that the primary cause of this impending crisis is the failure of States to transparently and equitably distribute the conservation burden and benefit, and thereby enable the adoption of sufficiently strong measures to reduce overfishing to sustainable levels and remove overcapacity. ${ }^{3}$ Determining the distribution of the conservation burden and benefit at the international level is a contentious issue as regional fisheries management organisations (RFMOs) struggle to respond to growing concerns regarding overfishing and overcapacity.

Given current levels of overfishing, conservation measures are required that reduce fishing mortality. Such conservation measures will impose a conservation burden or benefit on some or all participating States. In order to implement these measures, governments must fund national institutions to implement and govern national regulations, while potentially increasing the management costs on their fishing fleets and fishing grounds through limitations on fishing opportunities and more complex and costly licensing arrangements. Depending upon their structure, conservation measures will affect various participants directly and indirectly: reducing benefits for some; limiting opportunities for others; and protecting or even increasing benefits for yet others.

Conservation measures may also affect developing States that depend significantly on fisheries and have strong aspirations to further develop this resource. Some of these States may have few other development and resource options and will incur a relatively higher economic and social burden as a consequence of these conservation measures as compared to other States with diverse resources, large institutions and substantial revenue streams from multiple economic activities.

\footnotetext{
${ }^{1}$ FAO, The State of World Fisheries and Aquaculture (Food and Agriculture Organization of the United Nations [FAO], Italy, 2012).

${ }^{2}$ High Seas Task Force, Closing the Net: Stopping Illegal Fishing on the High Seas (Governments of Australia, Chile, Canada, Namibia, New Zealand and the United Kingdom plus WWF, IUCN and the Earth Institute, 2006). Accessed online June 2012 at: http://www.oecd.org/ sd-roundtable/aboutus/stoppingillegalfishingonthehighseas.htm.

${ }^{3}$ Q Hanich, 'Distributing the Bigeye Conservation Burden in the Western and Central Pacific Fisheries' (2012) 36 Marine Policy 327-332; Q Hanich, 'Distributing a Conservation Burden across Multiple Jurisdictions: A Case Study of the Western and Central Pacific Tuna Fisheries', in C Schofield, M-S Kwon, and S Lee (eds), The Limits of Maritime Jurisdiction (Brill/Martinus Nijhoff, The Hague, forthcoming).
} 
Thus, one can argue that the negotiation over the scope and application of a conservation measure is a negotiation over how the burden of conservation action is apportioned. The eventual decision will allocate the costs related to the conservation measures and the benefits that result (i.e., increased catch per unit of effort, enhanced fishing opportunities). Negotiations have to balance diverse interests and come to an agreement over how these interests are compromised. Nevertheless, RFMOs do not transparently study the likely distribution of the conservation burden and benefit that would arise from each potential management option. Instead, RFMOs address deeply political and economic arguments within a scientific framework. These frameworks then become politicized as members favour scientific assessments for measures that best protect their own interests, and refute scientific assessments for measures that compromise their interests. ${ }^{4}$ Consequently, these frameworks become political tools rather than effective management tools, creating room for participating countries to focus on individual interests rather than to search for the common ground required to achieve a useful outcome. Ultimately, the lack of a framework to address political and equity considerations undermines the fisheries science while still leaving the political and economic questions unanswered.

This article proposes that RFMOs adopt a new transparent approach to distributing the conservation burden and benefit in trans-boundary fisheries, and explores this approach in the world's largest tuna fishery: the tropical tuna fisheries of the western and central Pacific. The article recommends that RFMOs consider developing decision-making frameworks that enable fisheries science to determine the necessary extent of conservation measures, while a new conservation burden methodology would then determine the implementation of the measures and their impact on each member.

\section{The International Legal Framework for Distributing the Conservation Burden and Benefit in International Fisheries}

At the most basic level, it is important that the distribution of the conservation burden and benefit is consistent within the existing international legal framework. Given the multi-jurisdictional nature of international fisheries, it

\footnotetext{
${ }^{4}$ Policansky notes that "marine fishery-resource controversies are couched in scientific terms, although often they are not scientific disputes." D Policansky, 'Science and Decision Making in Fisheries Management' in T Pitcher, P Hart and D Pauly (eds), Reinventing Fisheries Management (Fish and Fisheries Series, Kluwer Academic Publishers, Netherlands, 2001) $57-71,67$.
} 
is important to recognise State sovereignty concerns and develop an approach that equitably addresses such concerns while working across all jurisdictions (the principle of sovereign equality allows States to authorise and undertake activities within their territory, free of external interference within internationally agreed limits). ${ }^{5}$

Beyond the foundation concept of State sovereignty, a legal framework for distributing the conservation burden is provided by the United Nations Convention on the Law of the Sea (LOSC), ${ }^{6}$ the United Nations Fish Stocks Agreement (UNFSA), ${ }^{7}$ the FAO Code of Conduct $^{8}$ and an umbrella of supplementary binding and non-binding agreements. Collectively, these agreements provide the international fisheries governance framework within which States cooperate and negotiate measures that apply and distribute a conservation burden and benefit. This framework is further elaborated by other binding and non-binding agreements, United Nations General Assembly Resolutions and decisions in case law that elaborate broad principles that may affect international fisheries governance and the distribution of any conservation burden or benefit. ${ }^{9}$

5 The Principle of Sovereign Equality was further articulated during the later 20th Century to recognise the permanent sovereignty that States have over their natural resources. However, these rights are limited by obligations to consider, and not infringe unduly upon, the sovereignty and sovereign rights of other States in their exercise of their own territorial sovereignty or sovereign rights. Declaration on Principles of International Law Concerning Friendly Relations and Co-operation Amongst States in Accordance with the Charter of the United Nations 2625 $(X X V)$; Twenty-Fifth Session of the United Nations General Assembly (New York, 24 October 1970). See also: Charter of the United Nations. Opened for signature 26 June 1945; entered into force 24 October 1945; New York, USA. Available at http://www.un.org/en/documents/ charter/intro.shtml. United Nations General Assembly Resolution 1803 (XVII), Permanent Sovereignty over Natural Resources, United Nations General Assembly (New York, 14 December 1962).

${ }^{6}$ United Nations Convention on the Law of the Sea (LOSC). Opened for signature 10 December 1982; entered into force 16 November 1994; Montego Bay, Jamaica (1982) 21 International Legal Materials 1261.

7 Agreement for the Implementation of the Provisions of the United Nations Convention of the Law of the Sea 10 December 1982, Relating to the Conservation and Management of Straddling Fish Stocks and Highly Migratory Fish Stocks (UNFSA). Opened for signature 4 August 1995, entered into force 11 December 2001, New York, USA, (1995) 34 International Legal Materials 1542.

${ }^{8}$ Code of Conduct for Responsible Fisheries, adopted at the 28th Session of the FAO Conference, 31 October 1995, Rome, Italy. Accessed online July 2012 at: http://www.fao.org/ docrep/005/v9878e/v9878e00.HTM.

9 For example, principles of sustainable and responsible development are derived from the broader environmental context of Agenda 21, the United Nations Conference on Environment and Development (UNCED) and the resultant Convention on Biological Diversity (CBD). For selected readings on Agenda 21, UNCED and the CBD and their impact on 
Four factors significantly influence what principles apply in the context of distributing a conservation burden and benefit. These are: the location of the fishing activity; requirements for cooperation and non-discriminatory participation; requirements to consider developing State concerns; and principles of conservation and management.

First, the location of the fishing activity is significant due to the zonal framework established by the LOSC. The LOSC recognises coastal State sovereignty over its internal waters, territorial seas and archipelagic waters ${ }^{10}$ and grants coastal States "absolute and unfettered" control over the exploitation, conservation and management of fisheries within these waters under State sovereignty. ${ }^{11}$ The LOSC prescribes no specific duty to cooperate in relation to fisheries in waters under State sovereignty (except for the limited obligation on archipelagic States regarding immediately adjacent neighbouring States). ${ }^{12}$ Other than a generalised obligation to protect and preserve the marine environment, ${ }^{13}$ the LOSC does not prescribe any obligation for coastal States to conserve or utilise fisheries within waters under sovereignty. ${ }^{14}$

Next, the LOSC grants coastal States sovereign rights over the exploitation, conservation and management of the natural resources within its Exclusive Economic Zone (EEZ). ${ }^{15}$ Coastal States do not hold sovereignty over their EEZ, but rather hold rights and responsibilities over the activities that occur within these waters, such as fisheries. ${ }^{16}$ The LOSC provides that fisheries within the EEZ can only be exploited with the consent of the coastal State, subject to specific provisions that oblige the coastal State to: manage and conserve fisheries in EEZs; ${ }^{17}$ promote their optimum utilisation and share their

fisheries governance, see: A Yankov, 'The Law of the Sea Convention and Agenda 21: Marine Environmental Implications' in A Boyle and D Freestone (eds), International Law and Sustainable Development: Past Achievements and Future Challenges (Oxford University Press, Oxford, 1999) 271-296. W T Burke, 'UNCED and the Oceans' (1993) 17 Marine Policy 519-533.

${ }^{10}$ Part II and Part IV, LOSC.

${ }^{11}$ E Hey, 'The Fisheries Provisions of the LOS Convention' in E Hey (ed) Developments in International Fisheries Law (Kluwer Law International, Netherlands, 1999) 13-29.

12 Parts II and IV, LOSC.

13 Part XII, LOSC.

${ }_{14}$ Hey, supra note 11.

${ }_{15}$ Article 56, LOSC.

${ }^{16}$ F Orrego Vicuna, The Exclusive Economic Zone: Regime and Legal Nature under International Law, Cambridge Studies in International and Comparative Law (Cambridge University Press, Cambridge, 1989).

17 Article 61, LOSC. 
surplus catch $;{ }^{18}$ and cooperate with other States and relevant organisations to ensure conservation and promote the optimum utilisation of fish stocks. ${ }^{19}$

For fisheries in waters beyond national jurisdiction, the LOSC continues the global commons status for the high seas and provides that no State may validly purport to subject any part of the high seas to its sovereignty. ${ }^{20} \mathrm{Simi}$ larly, the LOSC continues to apply the traditional freedom of the seas to the high seas, thereby granting all States an equal right to fish the high seas. ${ }^{21}$ An early consequence of these equal rights was the creation of an obligation not to interfere with the vessels of other States on the high seas, nor impose on their rights. ${ }^{22}$ The modern concept of flag State primacy devolved from original assertions that vessels at sea were figuratively a piece of territory of the State under whose flag they sailed. The LOSC builds upon this traditional principle and assigns exclusive flag State jurisdiction over vessels on the high seas. ${ }^{23}$ These flag State rights are balanced by obligations which impose a duty to cooperate and require flag States to manage their high seas fishing activities at sustainable levels. ${ }^{24}$

Second, given the international nature of these fisheries, a cooperative approach is required that enables compatible conservation and management measures to be implemented throughout the range of the stocks at the appropriate regional, sub-regional and national levels. The UNFSA elaborates a principle of compatible management which provides that coastal States and States fishing on the high seas have a duty to cooperate for the purpose of achieving compatible measures for straddling and highly migratory fish stocks in their entirety. ${ }^{25}$ In practice, this may require some compromises between

\footnotetext{
18 Article 62, LOSC.

19 Articles 61, 62, 69, 70, 71, 72 and 73, LOSC.

${ }^{20}$ Articles 86 and 89, LOSC.

${ }^{21}$ Article 87, LOSC. This concept of freedom of the seas was most famously developed and articulated by Hugo Grotius in 1604-05 in his book Mare Liberum. Grotius developed a substantial theoretical and historical argument that nature constituted the inexhaustible oceans and air for common use-that these were the common property of all. Behind the theory was the pragmatic purpose for the doctrine: defending the vested commercial interests of the Dutch against the extensive maritime claims of the Portuguese. After some contention, this principle came to dominate ocean governance and global fisheries for the next 400 years. $\mathrm{H}$ Grotius, The Freedom of the Seas (Oxford University Press, Oxford). This publication is a translation of the Latin text published in 1604 and was produced in 1916).

22 R Rayfuse, Non-Flag State Enforcement in High Seas Fisheries (Publications on Ocean Development, Martinus Nijhoff Publishers, Leiden, 2004).

${ }_{23}$ Articles 91, 92 and 94 of the LOSC are particularly relevant.

${ }_{24}$ Articles 61, 62, 63, 64, 116, 117, 118, 119, LOSC. This duty to cooperate is further elaborated for anadromous (Article 66) and catadromous stocks (Article 67), transboundary and straddling stocks (Article 63), and highly migratory stocks (Article 64).

25 Article 7.2, UNFSA.
} 
flag and coastal States as they ensure the compatibility of flag State measures for fleets fishing on the high seas with coastal State measures for fisheries in waters under national jurisdiction. ${ }^{26}$

While the UNFSA significantly expands obligations regarding cooperation for fisheries in EEZs and the high seas, it provides little guidance for coastal waters under State sovereignty. The general principles of the UNFSA specifically refer to the LOSC's duty to cooperate. ${ }^{27}$ Given that the LOSC prescribes a duty to cooperate only for fisheries within EEZs and on the high seas, it would appear reasonable to interpret the mandate for the UNFSA as also limited to EEZs and high seas. ${ }^{28}$ This interpretation is further supported by the UNFSA's Articles 3 and 7: these specifically refer to the protection of a coastal State's "sovereign rights" when discussing waters under national jurisdiction, and do not refer to any issues relating to sovereignty, as might occur in discussions regarding fisheries management within waters under State sovereignty.

The UNFSA expands upon the LOSC and standardises RFMOs as the appropriate form of cooperation, and requires fishing States and coastal States to give effect to their duty to cooperate by establishing an RFMO or arrangement where none exists. ${ }^{29}$ Where RFMOs exist, the UNFSA requires States to cooperate through joining, or participating in, a RFMO or arrangement, or at a minimum applying the conservation and management measures established by such organisations or arrangements. ${ }^{30}$

Perhaps most powerfully, the UNFSA explicitly prescribes that only those States which agree to implement measures of an existing RFMO (in regard to highly migratory and straddling stocks) shall have access to the fishery resources to which those measures apply. ${ }^{31}$ This extension of the duty to cooperate significantly extends the authority of relevant RFMOs as it indirectly binds all UNFSA parties to apply all relevant RFMO conservation measures, regardless of their status in relation to each RFMO. In effect, this limits the freedom to fish on the high seas for straddling and highly migratory fisheries and institutionalises the duty to cooperate (in regard to straddling and highly migratory

\footnotetext{
${ }^{26}$ A Oude Elferink, 'The Determination of Compatible Conservation and Management Measures for Straddling and Highly Migratory Fish Stocks' in J Frowein, R Wolfrum and C Philipp (eds), Max Planck Yearbook of United Nations Law (Kluwer Law International, Netherlands, 2001) 551-607.

${ }^{27}$ Article 5, UNFSA.

${ }^{28}$ Note that Article 3 of UNFSA qualifies its application to waters under national jurisdiction.

${ }^{29}$ Article 8.5, UNFSA.

30 Article 8, UNFSA.

${ }^{31}$ Article 8.4, UNFSA.
} 
fisheries) through the mechanism of RFMOs. ${ }^{32}$ Recent commentary indicates that UNFSA provisions relating to the duty to cooperate may be developing sufficient customary status under international law to also limit the freedom to fish for States that are neither party to the UNFSA, nor to the relevant RFMO. ${ }^{33}$

On the question of participation, it is important to note that RFMOs are under an obligation to operate in a non-discriminatory and transparent manner and open their membership to States with a "real interest". The LOSC and the UNFSA establish basic principles that States shall cooperate to establish fisheries organisations and that the States concerned shall ensure that conservation measures and their implementation do not discriminate in form or in fact against the fishermen of any State. ${ }^{34}$ Neither the LOSC nor the UNFSA offer further guidance on the definition of "real interest". Although the definition of "real interest" is unclear, the general view is that the concept of real interest should not be interpreted in an exclusive manner. ${ }^{35}$ In the context of distributing a conservation burden or benefit, at a minimum, adjacent coastal States and states fishing for stocks on the high seas inside the area in question are generally regarded as having a real interest and therefore have a right to participate in the relevant RFMOs. ${ }^{36}$

Deliberations over participatory rights are determined within the zonal framework established by the LOSC. Coastal States hold exclusive rights to fisheries within their waters, while all flag States and adjacent coastal States share participatory rights over fisheries on the high seas, as qualified by the LOSC, the UNFSA, and the relevant RFMO. In this context, it is important to distinguish between participatory rights and allocations made through a rights-based management approach. Participatory rights simply recognise the right of a State to allow its vessels and nationals to participate in a fishery. Allocation determines what share of the fishery that each State may hold. It is possible that a State may have participatory rights for its vessels and nationals to fish within a RFMO's jurisdiction, but not have any allocation for those

\footnotetext{
32 Rayfuse argues that UNFSA operationalises the duty to cooperate: "perhaps the single most significant aspect of this operationalisation, is the 'institutionalisation' of the duty to cooperate by requiring its exercise through RFOs (RFMOs)." Rayfuse, supra note 22, at 43 .

33 T Henriksen, 'Revisiting the Freedom of Fishing and Legal Obligations on States Not Party to Regional Fisheries Management Organisations' (2009) 40 Ocean Development and International Law 80-96.

34 Articles 118 and 119.3, LOSC; Article 8.3, UNFSA.

35 E Molenaar, 'The Concept of Real Interest and Other Aspects of Cooperation Through Regional Fisheries Management Mechanisms' (2000) 15 International Journal of Marine and Coastal Law 475-531.

${ }^{36}$ Ibid.
} 
vessels to fish. In this case, these vessels would need to purchase access to the fishery from a coastal State with a surplus, or trade an allocation with another flag State.

The UNFSA provides for the issue of allocation as a substantive matter for RFMOs to consider, but does not consider it a fundamental requirement. It is qualified by the words "as appropriate," and allows RFMOs the flexibility to determine whether it is appropriate to their regional circumstances to allocate rights to the fisheries within their jurisdiction. ${ }^{37}$ Similarly, the FAO Code of Conduct does not prescribe allocation processes but advises that in order to assist decision-making on the allocation and use of coastal resources, States should promote the assessment of their respective values taking into account economic, social and cultural factors. ${ }^{38}$

The third factor that must be considered when distributing a conservation burden or benefit in international fisheries is the impact of any conservation burden on developing States and artisanal fishers. The special requirements and needs of developing States, particularly small island developing States, are recognised at a global level. ${ }^{39}$ The UNFSA requires that States shall take into account the special requirements of developing States when giving effect to the duty to cooperate. In effect, RFMOs must consider: the vulnerability of developing States that are dependent on the exploitation of fisheries, including food security concerns; the need to avoid adverse impacts on, and ensure access to fisheries by, subsistence, small-scale and artisanal fishers and women fishworkers, as well as indigenous people in these States, particularly small island developing States; and the need to ensure that measures do not result in transferring, directly or indirectly, a disproportionate burden of conservation action onto developing States. ${ }^{40}$ At the global level, the UNFSA articulates the principle that the global community interest in the conservation of fisheries

\footnotetext{
37 Article 10, UNFSA.

38 Paragraph 10.2.2, FAO Code of Conduct. Accessed online July 2012 at: http://www.fao .org/docrep/005/v9878e/v9878e00.HTM.

39 Consideration of these requirements, and of the importance of marine resources to the sustainable development of small island states, has also been included within other globally significant but not legally binding documents, such as the Barbados Programme of Action for the Sustainable Development of Small Island Developing States and the World Summit for Sustainable Development's (WSSD) Johannesburg Plan of Implementation. Barbados Programme of Action for the Sustainable Development of Small Island Developing States. Global Conference on the Sustainable Development of Small Island Developing States. (Bridgetown, Barbados 25 April to 6 May 1994). Johannesburg Plan of Implementation on Sustainable Development. World Summit on Sustainable Development. (Johannesburg, South Africa, 26 August to 4 December 2002).

40 Article 24, UNFSA.
} 
should not result in a disproportionate burden of conservation action on developing States. ${ }^{41}$

Modern international fisheries governance also explicitly recognises the concerns of artisanal and subsistence fishers. The UNFSA and the FAO Code of Conduct both set out the principle that RFMO members shall take into account the interests of artisanal and subsistence fishers when giving effect to their duty to cooperate ${ }^{42}$ and avoid adverse impacts on, and ensure access to fisheries by, subsistence, small-scale and artisanal fishers and fishworkers, as well as indigenous people in developing States parties, particularly small island developing States parties, and territories and possessions. ${ }^{43}$ The LOSC also explicitly refers to the interest of fishing communities in regard to the establishment of conservation and management measures for EEZs. ${ }^{44}$

Fourth, modern international fisheries governance sets out conservation and management principles that directly affect the adoption of conservation and management measures, and the subsequent extent of any conservation burden. The LOSC, the UNFSA and various other global fisheries and environment agreements require that conservation and management decisions shall be based on the best scientific evidence available, ${ }^{45}$ and take into account traditional knowledge of the resources and their habitat ${ }^{46}$ as well as relevant environmental and economic ${ }^{47}$ and social factors, ${ }^{48}$ including the special requirements of developing States. ${ }^{49}$

Fisheries science has an inherently high degree of uncertainty which can be a significant obstacle to fisheries management. ${ }^{50}$ Modern international fisheries

${ }^{41}$ L Juda, 'The 1995 United Nations Agreement on Straddling Fish Stocks and Highly Migratory Fish Stocks: A Critique' (1997) 28 Ocean Development and International Law 147-166.

42 Article 5, UNFSA; Paragraph 7.7.2(c), FAO Code of Conduct.

43 Article 24.2(b), UNFSA.

${ }^{44}$ Article 61, LOSC. In addition, Schram and Tahindro argue that recognition of coastal State rights and duties in Article 116 of the LOSC sufficiently encompasses coastal fishing communities to allow for their consideration in regard to high seas fisheries. G G Schram and A Tahindro, 'Developments in Principles for the Adoption of Fisheries Conservation and Management Measures' in Hey, supra note 11 at 251-286.

45 Articles 61 and 119, LOSC; Article 5, UNFSA; Paragraph 6.4, FAO Code of Conduct.

46 Paragraph 6.4, FAO Code of Conduct.

${ }^{47}$ Articles 61 and 119, LOSC; Article 5, UNFSA; Paragraph 6.4, FAO Code of Conduct.

48 Paragraph 6.4; FAO Code of Conduct.

49 Articles 61 and 119, LOSC; Article 5, UNFSA.

${ }^{50}$ Butterworth describes fisheries assessment as an inexact science "in which uncertainty is pervasive" and Christensen and Pauly note that the level of uncertainty in fisheries stock assessments can be formidable. D Butterworth, 'Science and Fisheries Management: Entering the New Millennium' in M H Nordquist and J Moore (eds), Current Fisheries Issues and the Food and Agriculture Organization of the United Nations (Martinus Nijhoff Publishers, Boston, 2000) 37-54, 39; V Christensen and D Pauly, 'Placing Fisheries in their Ecosystem Context, An Introduction' (2004) 172 Ecological Modelling 103-107. 
governance partly accounts for this inherent uncertainty by setting a low benchmark at "best available scientific evidence", implying that decisions shall be based on weak or poor science if that is recognised as the best available. Such uncertainties are further addressed through the application of a precautionary approach which requires that States "shall be more cautious when information is uncertain, unreliable or inadequate". ${ }^{51}$ States must not use the absence of adequate scientific information as a reason for postponing or failing to take conservation and management measures. ${ }^{52}$ The precautionary approach considers potential long-term impacts on living marine resources and their environment, and requires the development of reference points and decision-making rules to avoid or mitigate undesirable outcomes. ${ }^{53}$

The UNFSA and the FAO Code of Conduct incorporate principles that apply a "precautionary approach widely to conservation and management of straddling fish stocks and highly migratory fish stocks in order to protect the living marine resources and preserve the marine environment" ${ }^{54}$ In addition, they also build on LOSC provisions relating to associated and dependent spe$\operatorname{cies}^{55}$ and elaborate an ecosystem-based approach to fisheries management that recognises the interrelated nature of marine ecosystems. ${ }^{56}$ This includes establishing standards for the protection of marine biodiversity and the assessment, management, minimisation and monitoring of impacts on associated and dependent species and the marine environment. ${ }^{57}$ The FAO subsequently coordinated a number of activities and papers that further developed principles for an ecosystem-based approach, including the principle that "governance should ensure both human and ecosystem well-being and equity" 58

\footnotetext{
${ }^{51}$ Article 6.2, UNFSA.
}

${ }_{52}$ Article 6.2, UNFSA; Paragraph 7.5, FAO Code of Conduct.

53 Article 6 and Annex II, UNFSA. Undesirable outcomes include: "overexploitation of resources, overdevelopment of harvesting capacity, loss of biodiversity, major physical disturbances of sensitive biotopes, or social or economic dislocations." For further elaboration, see: FAO, Precautionary Approach to Capture Fisheries and Species Introductions. Elaborated by the Technical Consultation on the Precautionary Approach to Capture Fisheries (Including Species Introductions) (Food and Agriculture Organization of the United Nations, Rome, 1995).

${ }_{54}$ Article 6, UNFSA. Similar language occurs in Paragraph 7.5.1, Code of Conduct.

55 Articles 61 and 119, LOSC.

56 Article 192 of the LOSC established the principle that all States have an obligation to protect and preserve the marine environment. This obligation is universal within the context of the LOSC and applies to all activities and all waters, including waters under national jurisdiction. Articles 61 and 119 applied this principle directly to fisheries and established the framework for an ecosystem-based approach to fisheries management. For further discussion, see: H Wang, 'Ecosystem Management and its Application to Large Marine Ecosystems: Science, Law and Politics' (2004) 35 Ocean Development and International Law 41-74.

57 Articles 5 and 6, UNFSA.

58 FAO, Fisheries Management \#2 - The Ecosystem Approach to Fisheries (Food and Agriculture Organization of the United Nations, Rome, 2003). 
These developments build on provisions within the Code of Conduct and focus significantly on social and inter-generational equity concerns. ${ }^{59}$

A critical question of interpretation arises when considering the implementation of an ecosystem-based approach to fisheries management in the context of distributing a conservation burden or benefit. The FAO Technical Guidelines note that mixed-species fisheries require consideration of the different vulnerabilities and productivities of the various species that may be caught together. ${ }^{60}$ For example, the western and central Pacific purse-seine fishery captures skipjack, yellowfin and bigeye tuna. Each of these species has significantly different characteristics. In such circumstances, the Guidelines recommend, inter alia, that catch limits for target species may need to be modified to control catches of more vulnerable species. ${ }^{61}$ However, the FAO Technical Guidelines and the UNFSA both allow for the consideration of human "wellbeing and equity" and "... economic factors, including the special requirements of developing States." ${ }_{2}$ This could be interpreted as allowing for the adoption of catch or effort limits that would be sustainable for skipjack, but result in significant levels of overfishing for bigeye if such measures were to protect developing coastal States who primarily benefit from purse-seine catches of skipjack, and receive little benefit from bigeye.

This question of interpretation presents a key challenge for RFMOs as they consider conservation measures that apply a conservation burden or provide a benefit. The multi-species and multi-gear characteristics of many international fisheries, such as tuna, are likely to create significant challenges for the establishment of target and limit reference points, and for agreed management responses. For example, some Pacific island coastal States argue that the explicit reference to "as qualified by relevant environmental and economic factors" allows for conservation measures that would allow continued overfishing of bigeye in order to promote the optimum utilisation of skipjack and albacore, as long as the bigeye biomass remains above a limit reference point sufficient to ensure long-term levels of reproduction and recruitment. ${ }^{63} \mathrm{On}$ the other hand, some commentators have argued that such an approach might

\footnotetext{
59 These developments are important because they prescribe internationally recommended standards that were developed through global consultative processes. Article 5 UNFSA requires States to take into account generally recommended international minimum standards and recommended practices and procedures).

${ }^{60} \mathrm{FAO}$, Fisheries Management \#2, supra note 58.

${ }^{61}$ Ibid.

${ }^{62}$ Article 5(b), UNFSA.

${ }^{63}$ L Clarke, 'Implementation of the Precautionary Approach and Reference Points' in Q Hanich and M Tsamenyi (eds), Navigating Pacific Fisheries: Legal and Policy Trends in the Implementation of International Fisheries Instruments in the Western and Central Pacific Region (Australian National Centre for Ocean Resources and Security, Wollongong, 2009) 284-301.
} 
be inconsistent with the provisions in the LOSC relating to associated and dependent species and that it would be "improper to ensure the maintenance of one or more living resources by endangering one or more other stocks". ${ }^{64}$

In summary, the operation of these four factors (i.e. location, participation, developing status, and conservation requirements) frames the distribution of the conservation burden and benefit in the following ways. If the fishing activity in question occurs within waters under State sovereignty, then conservation is almost entirely at the discretion of the coastal State, subject to the responsibility to not cause harm to others and a general LOSC responsibility on all parties to protect and preserve the marine environment, and related requirements in LOSC Part XII. ${ }^{65}$ If the fishing activity occurs within an EEZ, or on the high seas, then the responsible coastal and flag States are required to cooperate and implement conservation measures in accordance with the principles of international fisheries governance discussed above, including the requirements of LOSC Part XII. RFMOs are the formally endorsed mechanism in international law for such cooperation and they are required to implement the principles identified above relating to participation, decision-making and conservation (including precautionary and ecosystem-based approaches to fisheries management). It is important to note that RFMOs are also explicitly required to ensure that conservation measures do not result in transferring, directly or indirectly, a disproportionate burden of conservation action onto developing States.

\section{Key Questions for Distributing the Conservation Burden and Benefit}

Existing processes fail to successfully resolve the political aspects of conservation negotiations, and consequently RFMO members are proving to be unwilling to reach a compromise with regard to their interests. Measures are opposed or weakened as each member argues for exemptions, or will only support measures that will minimally affect their own interests. ${ }^{66}$ Some commentators argue that some form of property or use right must be distributed among participants in order to address overfishing and reduce excess capacity effectively. ${ }^{67}$ A rights-based management approach allocates fishing rights to

${ }^{64}$ B Applebaum and A Donohue, 'The Role of Regional Fisheries Management Organisations' in Hey, supra note 11 at 217-249.

${ }^{65}$ Article 192, LOSC.

${ }^{66} \mathrm{Q}$ Hanich, Interest and Influence-A Snapshot of the Western and Central Pacific Tropical Tuna Fisheries (Australian National Centre for Ocean Resources and Security, Wollongong, 2011). Available at http://ro.uow.edu.au/uowbooks/1.

${ }^{67}$ For selected readings on rights-based management, see: V Kaitala and G Munro, 'The Management of High Seas Fisheries' (1993) 8 Marine Resource Economics 183-196; R Allen, W Bayliff, J Joseph and D Squires, 'Rights-Based Management in Transnational Tuna Fisheries' 
stakeholders (i.e., fishers, vessels, companies, cooperatives, and fishing communities) and defines the limits and usage of these rights. Such an approach allocates the benefits of the fishery. Proponents suggest that the lack of specific rights in a fishery undermines incentives for conservation, whereas a rightsbased management approach would give stakeholders incentives to fish in a manner that ensured the long-term sustainability and economic viability of the fishery. ${ }^{68}$

However, applying rights-based management approaches to international fisheries requires first that the participating coastal and flag States agree on their national allocations before these rights can be assigned further down to stakeholders. Determining such rights through an explicit allocation process is highly fraught and can consume years of effort, particularly as allocation decisions generally require consensus. ${ }^{69}$ These challenges are further exacerbated for international fisheries that include significant catches from waters under national jurisdiction and the high seas. ${ }^{70}$ Consequently, RFMOs have found it immensely difficult to reach agreement on basic principles to determine allocations between States. While energies are focused on allocation negotiations, overfishing may continue and could potentially be exacerbated as the consideration of historical catch in allocation negotiations encourages a race-to-fish mentality to build up a catch history. ${ }^{71}$ Where RFMOs have allocated rights to a fishery, these have sometimes failed to limit fishing catches or

in R Allen, J Joseph, D Squires (eds), Conservation and Management of Transnational Tuna Fisheries (Wiley-Blackwell, Ames, Iowa, 2010) 65-86.

${ }^{68}$ J Joseph, D Squires, W Bayliff and T Groves, 'Addressing the Problem of Excess Fishing Capacity in Tuna Fisheries' in Allen et al., ibid., at 11-38; A Willock and I Cartwright, Conservation Implications of Allocation under the Western and Central Pacific Fisheries Commission (WWF Australia and TRAFFIC Oceania, Sydney, 2006).

${ }^{69}$ M Lodge, D Anderson, T Lobach, G Munro, K Sainsbury and A Willock, Recommended Best Practices for Regional Fisheries Management Organisations: Report of an Independent Panel for Improved Governance by Regional Fisheries Management Organisations (Chatham House, London, 2007).

${ }^{70}$ In 2010, the Japanese government stated at an international tuna workshop that allocation was a very difficult issue, particularly in the context of the WCPO tuna fisheries where much of the catch is taken from within EEZs. Personal notes. Comments by Masanori Miyahara, Chief Counsellor. Fisheries Agency of Japan. Commissioner and Head Delegate to the WCPFC. Comments made on 30 June 2010 at Kobe II International Workshop on RFMO Management of Tuna Fisheries. (Brisbane, Australia. 29 June to 1 July 2010).

${ }^{71}$ A "race to fish" can occur where fleets attempt to rapidly build up a catch history to support imminent negotiations for an allocation that may be partly or wholly based on their historical catch. M Lodge and S Nandan, 'Some Suggestions Towards Better Implementation of the United Nations Agreement on Straddling Stocks and Highly Migratory Fish Stocks of 1995' (2005) 20 International Journal of Marine and Coastal Law 345-379. 
effort, as agreed limits have been subsequently increased to accommodate new entrants. ${ }^{72}$

Some RFMOs have deferred any explicit allocation of the benefits of the fishery due to failures to agree on basic principles, but have nevertheless distributed a conservation burden and benefit through the adoption of conservation and management measures. In the stalemate vacuum that surrounds rights-based management failures, the distribution of the conservation burden and benefit becomes in effect an interim reverse allocation. However, this approach does not support the negotiation of strong measures because it does not provide a transparent or equitable framework for a politically acceptable distribution of the conservation burden and benefit. Furthermore, these implicit allocations last only as long as the conservation and management measures are in force.

And herein lies the problem, and an opportunity. Rather than continue attempts to fit stakeholder-based rights-based management into an international context, this article proposes that RFMOs adopt a new approach to the distribution of the conservation burden and benefit. This should work within existing international principles of fisheries governance and expand conservation negotiations to include a transparent methodology for the equitable distribution of the conservation burden and benefit. This article suggests that it is likely to be more productive to build on the conservation momentum and establish a transparent framework that defines the parameters for how it distributes the conservation burden and benefit. This would also avoid disagreements regarding whether RFMOs can extend allocation regimes into EEZs.

Most importantly, such an approach would answer important equity questions that are fundamental to transparency in conservation and management negotiations and provide clarity and certainty to conservation negotiations. Some of these equity questions are presented in Table 1.

\section{Developing a New Approach to the Distribution of the Conservation Burden and Benefit}

This article proposes that RFMOs develop a new approach for addressing these questions, implemented through decision-making frameworks that transparently and equitably distribute the conservation burden and benefit.

${ }^{72}$ C Hedley, R Churchill and L De La Fayette, Perspectives for the United Nations Fish Stocks Agreement (European Parliament, Directorate-General for Internal Policies of the Union, Brussels, 2007). Accessed online July 2012 at: http://www.fao.org/docrep/005/v9878e/ v9878e00.HTM. 
Table 1. Questions of Equity in Distributing the Conservation Burden and Benefit

\begin{tabular}{ll}
\hline Factors & Questions of Equity \\
\hline \hline $\begin{array}{l}\text { Coastal States } \\
\text { and Flag States }\end{array}$ & $\begin{array}{l}\text { Should RFMOs value the shared nature of } \\
\text { (flag State) common rights to high seas fish- } \\
\text { eries as equal or less than the exclusive nature } \\
\text { of (coastal State) sovereign rights over fisher- } \\
\text { ies within EEZs? How should these rights be } \\
\text { weighed against the absolute sovereignty that } \\
\text { coastal States hold over fisheries within their }\end{array}$ \\
$\begin{array}{l}\text { Food Security } \\
\text { for Coastal }\end{array}$ & $\begin{array}{l}\text { How should RFMOs consider the limited } \\
\text { options available to artisanal communities in }\end{array}$ \\
$\begin{array}{l}\text { coastal developing States, compared to the } \\
\text { diversity of food enjoyed by consumers in }\end{array}$ \\
$\begin{array}{l}\text { distant markets? } \\
\text { Subsistence } \\
\text { Fishing Com- } \\
\text { munities }\end{array}$ & $\begin{array}{l}\text { How should RFMOs balance the distribu- } \\
\text { tion of the conservation burden between } \\
\text { artisanal and subsistence fisheries compared } \\
\text { to large-scale industrial fishing fleets? }\end{array}$
\end{tabular}

Polluter Pays or Race to Fish

Mixed Benefits and Costs in Multi-gear and Multi-species Fisheries

Development Aspirations

New entrants

How should the development aspirations of developing States be recognised in practice? "polluter pays" into fisheries measures and focus the conservation burden on those States who are historically responsible for overfishing, or focus the distribution of the conservation burden on new entrants, protecting States with historically high fishing levels.

How should RFMOs recognise the mixed benefits and costs in multi-gear/multi-species fisheries?$$
\text { developing States be recognised in practice? }
$$

Considerations

LOSC and UNFSA prescribe no specific duty to cooperate or conservation responsibilities on coastal States for waters under State sovereignty. UNFSA protects coastal State and flag State rights under the LOSC.

UNFSA requires RFMOs to consider the vulnerability and needs of developing States which are dependent on fisheries for food security.

LOSC and UNFSA require consideration of artisanal and subsistence interests, but makes no such similar accommodation for industrial fleets. Similarly, UNFSA requires RFMOs to consider the needs of coastal States whose economies are dependent mainly on fishing for the stocks in question, but provides no such explicit requirement for consideration of distant-water fishing fleets (beyond the general equal consideration of "... respective interests, fishing patterns and fishing practices of new and existing members...".

Neither LOSC nor UNFSA provides guidance on whether States with a historical interest, or new entrants, should be protected or punished. UNFSA prescribes that various issues, including historical levels and the respective interests of new entrants and historically active participants must be considered, but does not value their interests.

If one fleet (e.g., longline) will benefit from conservation-related reductions in fisheries, should those States with significant interests in that fleet bear a greater share of the conservation burden than those States with minimal interests who will receive no direct benefit from those reductions.

International fisheries governance prescribes that RFMOs must not transfer a disproportionate burden of conservation action onto developing States, but provides no such protection for developed States. How should States account for new entrants UNFSA prescribes that various issues, includ-
in a manner that is consistent with the LOSC ing historical levels and the respective interests and UNFSA while recognising the fully of new entrants and historically active particifished/overfished nature of most international pants must be considered but does not value fisheries? 
Such a new approach would move beyond the conceptual level of rights-based models and provide concrete steps that explicitly determine what conservation burden or benefit each State would carry, depending on their national characteristics. This would modernise fisheries management to be more consistent with broader developments in common resource management (such as climate change) that incorporate principles of differentiated responsibilities (between developed and developing States). ${ }^{73}$

The approach would address the questions identified above and define the areas of interest relevant to the distribution of the conservation burden, consistent with core principles of international fisheries governance. These areas of interest could include the following:

- Coastal State interests in their waters under State sovereignty and in their EEZ:

- Opportunity for domestic fleets and artisanal fishers to fish inside national waters;

- Opportunity to provide immediate food security for coastal communities;

- Opportunity to license foreign vessels to fish in national waters.

- Flag State distant-water fishing interests

- Opportunity for registered vessels to fish.

- Market/consumer interests

- Opportunity to supply processing operations;

- Opportunity to supply commercial markets.

- Development aspirations

- Opportunities to develop domestic fishing fleets;

- Opportunities for domestic fishing fleets to fish in national waters, adjacent high seas, and further beyond;

- Opportunities to develop and supply domestic processing operations.

The approach would then develop a methodology for distributing the conservation burden and benefit, based on specific values for each area of interest. Agreement on the values for each area would be developed in accordance with the international principles identified above and international practice. For example, values for interests in waters under sovereignty would need to

${ }^{73}$ Article 3, United Nations Framework Convention on Climate Change, opened for signature 4 June 1992; entered into force 21 March 1994, New York (1992) 31(4) International Legal Materials 851. 
consider the higher level of rights compared to the more limited sovereign rights that apply to EEZs, or the common rights that apply to the high seas.

The methodology would then prescribe the use of these values and how they would be applied to conservation measures. For example, if a limit reference point were exceeded, an independent fisheries science provider or RFMO scientific committee would determine the extent of the necessary conservation response to reduce fishing mortality down to the level of the target reference point. The fisheries science provider would then advise on the conservation measure options that would achieve this conservation response and their necessary extent (i.e., restrictions or prohibitions on certain types of gear, areal and seasonal closures, capacity limits, catch/effort limits). This advice would only identify management options that are sufficient to achieve the necessary conservation response.

The methodology would then measure the impact of these alternative management options against the identified areas of interest and their agreed values. The methodology would then determine which of the alternate management options affected the areas of interest and values the least. The decision-making framework would then prescribe that this minimal impact option be adopted.

Such an approach would separate the scientific advice from the distribution of the conservation burden and benefit and therefore de-politicise the scientific assessments and advice to a significant degree. Members would also be assured that their interests would be transparently and equitably considered in accordance with the agreed framework.

Ideally the approach would work alongside a harvest strategy that identifies target and limit reference points and prescribes management responses. In this context, the management response to an exceeded limit reference point would be to invoke the agreed methodology for distributing the conservation burden and benefit and develop a conservation measure in accordance with its preagreed values. To demonstrate the approach, we present a case study below of how such a process might work in the context of the Western and Central Pacific Ocean (WCPO) tuna fisheries.

\section{A Case Study of the WCPO Tuna Fisheries-Political and Economic Interests}

The WCPO stretches approximately 6,000 nautical miles across numerous jurisdictions, from the archipelagos of Southeast Asia to the remote atolls of Kiribati in the Central Pacific. This vast ocean is home to the world's most productive tuna fisheries, supplying global markets with skipjack, bigeye, 
yellowfin and albacore worth approximately US $\$ 4.6$ billion. ${ }^{74}$ While albacore catches are significant in local fisheries, the region is dominated by the largescale tropical longline and purse-seine fisheries for skipjack, yellowfin and bigeye. Fourteen States collectively dominate these tropical tuna fisheries and include: China, Chinese Taipei, Federated States of Micronesia, Indonesia, Japan, Kiribati, the Marshall Islands, Nauru, Papua New Guinea, the Philippines, Solomon Islands, South Korea, Tuvalu, and the United States. ${ }^{75}$

These fisheries are critically different from other tuna fisheries in that $87 \%$ of all reported WCPO tuna catches are harvested from waters under national jurisdiction. ${ }^{76}$ Unlike the high seas tuna fisheries of the Eastern Pacific, Indian Ocean and North Atlantic, the rights to the WCPO tuna fisheries are predominantly owned by a small group of developing coastal States. Fishing fleets depend upon access to these waters for their financial viability. No surface fishing fleet, either distant water or locally based, can profitably operate pole and line or purse-seine vessels without some access to waters under national jurisdiction. ${ }^{77}$

Nine of the coastal States identified above also control significant areas of archipelagic waters. Fiji, Indonesia, Papua New Guinea, the Philippines and Vanuatu have all submitted claims for archipelagic status that are in accordance with the LOSC and broadly recognised..$^{78}$ The Solomon Islands is also considered to be an archipelagic State under the LOSC. ${ }^{79}$ In accordance with the LOSC, these States are all entitled to claim sovereignty over substantial archipelagic waters. Kiribati, the Marshall Islands and Tuvalu have also made declarations claiming archipelagic status, but these are inconsistent with the LOSC and are not shown on regional maps (see Fig. 1). ${ }^{80}$

\footnotetext{
${ }^{74}$ Average delivered value 2008 to 2010. Derived from P Terawasi and L Rodwell, Value of WCPO Tuna Fisheries (Excel database) (Pacific Islands Forum Fisheries Agency, Honiara, Solomon Islands, 2011).

75 Calculations based on data derived from ibid.

${ }^{76}$ Calculations based on data derived from ibid.

77 G Van Santen and P Muller, Working Apart or Together: The Case for a Common Approach to Management of Tuna Resources in Exclusive Economic Zones of Pacific Island Countries (The World Bank, Washington, D.C., 2000).

${ }^{78}$ United Nations, Maritime Space: Maritime Zones and Maritime Delimitation (2012). Available at: http://www.un.org/Depts/los/LEGISLATIONANDTREATIES/asia.htm; accessed on 10 July 2012; R R Churchill and A V Lowe, The Law of the Sea (3rd ed., Melland Schill Studies in International Law, Manchester University Press, Manchester, 1999).

${ }^{79}$ Churchill and Lowe, ibid.

${ }^{80}$ United Nations Office of Legal Affairs, United Nations Convention on the Law of the Sea: Declarations and Reservations (UN Publications, 2010). Accessed online July 2012 at: http:// www.un.org/Depts/los/doalos_publications/doalos_publications.htm; Churchill and Lowe, ibid.
} 


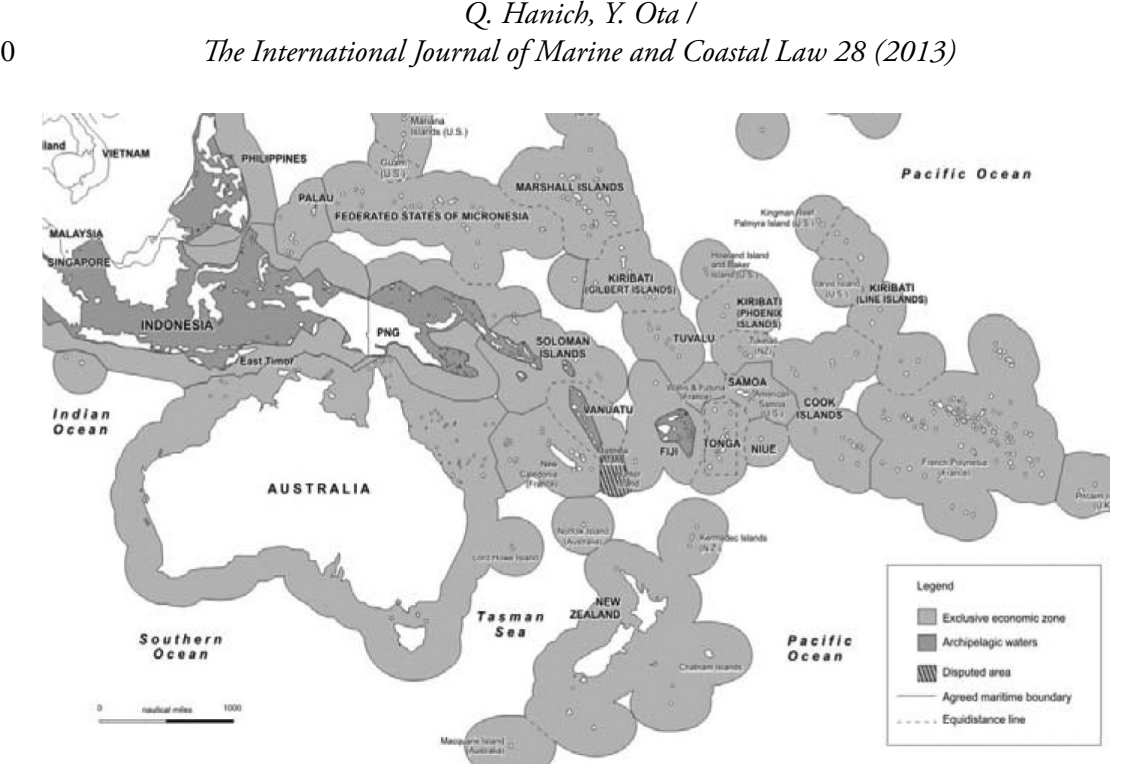

Fig. 1. The WCPO. ${ }^{81}$

The mandated RFMO for these fisheries is the Western and Central Pacific Fisheries Commission (WCPFC), which was established in 2004 and includes all of the key coastal and distant-water fishing States. ${ }^{82}$ The WCPFC faces a complex conservation and management challenge. The scientific assessments indicate that urgent action is required to address overfishing and reduce fishing mortality for bigeye, halt any increases in fishing mortality for yellowfin, reduce fishing mortality of juvenile bigeye and yellowfin, and develop precautionary limits for skipjack. ${ }^{83}$ The conservation challenge is complicated by the multi-gear, multi-species and multi-national characteristics of the WCPO tropical tuna fisheries. Each species of tropical tuna is caught by each gear in a tightly intermeshed manner that is difficult, if not impossible, to separate. This complexity is exacerbated by the substantially different biological characteristics of skipjack, yellowfin and bigeye (i.e., highly resilient and productive skipjack compared to the longer-lived and less productive bigeye).

${ }^{81}$ Map sourced from: Q Hanich, C Schofield and P Cozens, 'Oceans of Opportunity? The Limits of Maritime Claims in the Western and Central Pacific Region' in Hanich and Tsamenyi, supra note 63 at $21-50$.

82 Convention on the Conservation and Management of Highly Migratory Fish Stocks in the Western and Central Pacific Ocean (WCPF Convention). Opened for signature 5 September 2000, entered into force 19 June 2004, Pohnpei, Federated States of Micronesia. Available at http:// www.wcpfc.int.

83 WCPFC, Report of the Seventh Regular Session of the Scientific Committee of the Western and Central Pacific Fisheries Commission (Western and Central Pacific Fisheries Commission, Pohnpei, Federated States of Micronesia, 9-17 August 2011). 
This intermeshed nature makes it extremely challenging to address a specific management challenge, such as overfishing of bigeye, with a narrowly focused management response. For example, the bigeye fishery is targeted almost entirely by longline vessels. However, the increasing use of fish aggregating devices (FADs) by the purse-seine fishery has resulted in a significant bycatch of juvenile bigeye. ${ }^{84}$ Purse-seine sets on schools associated with FADs and logs will catch smaller fish, particularly juvenile yellowfin and bigeye, whereas sets on unassociated free-swimming schools (i.e., non-FAD sets) will catch larger skipjack and adult yellowfin. ${ }^{85}$ Proponents argue that FADs have increased the efficiency of purse seining, ${ }^{86}$ while others note that the significant reduction in the size of fish caught undermines the efficiency gains. ${ }^{87} \mathrm{In}$ addition to their significant impacts on bigeye and high levels of juvenile catch, scientists have raised concerns that the use of FADs may be creating an "ecological trap" ${ }^{88}$

For the WCPFC to resolve the threat to bigeye, it must reduce longline catches, but also restrict the operation of purse-seine vessels utilising FADs that inadvertently catch bigeye while targeting the highly productive skipjack (not currently threatened by overfishing). Purse-seine fleets receive little benefit from bigeye catches and so will receive little or no long-term sustainability benefit or increase in profitability if bigeye stocks rebuild. On the other hand, longline fleets will directly benefit from conservation measures that rebuild bigeye stocks as this will increase the profitability of longline fleets through improvements to their catch per unit of effort (CPUE). Balancing the interests between purse seine and longline, FAD and free school, high seas and

${ }^{84}$ N Davies, S Hoyle, S Harley, A Langley, P Kleiber and J Hampton, Stock Assessment of Bigeye Tuna in the Western and Central Pacific Ocean (Western and Central Pacific Fisheries Commission, Pohnpei, Federated States of Micronesia, 9-17 August 2011). Available at http://www.wcpfc.int.

85 A Langley, A Wright, G Hurry, J Hampton, T Aqorau and L Rodwell, 'Slow Steps Towards Management of the World's Largest Tuna Fishery' (2009) 33(2) Marine Policy 271-279.

${ }^{86} \mathrm{~J}$ Moron, J Areso and P Pallares, Statistics and Technical Information About the Spanish Purse Seine Fleet in the Pacific (14th Meeting of the Standing Committee on Tuna and Billfish, Noumea, New Caledonia, 9-16 August 2001).

${ }^{87}$ A Fonteneau, P Pallares, J Sibert and Z Suzuki, 'The Effect of Tuna Fisheries on Tuna Resources and Offshore Pelagic Ecosystems' (2002) 16 Ocean Yearbook 142-170.

${ }^{88}$ An ecological trap is an event whereby population growth is reduced due to individuals making poor habitat choices. Studies have suggested that tuna associated with FADs are less healthy than those in unassociated free-swimming schools. It has also been pointed out that the use of FADs is introducing further uncertainties into scientific assessments due to their impact on tuna behaviour. P Hallier and D Gaertner, 'Drifting Fish Aggregation Devices Could Act as an Ecological Trap for Tropical Tuna Species' (2008) Marine Ecology Progress Series 255-264. 
EEZs are all important factors in the distribution of the conservation burden and benefit. Another important factor is the benchmark year(s) to use to determine historical catch and effort levels.

The following figures illustrate some of these interests through providing an approximate indication of each State's interest in these issues. These figures are based on an analysis of reported catches from within the WCPFC Statistical Area (the perceived range of the stocks) and are based on the most recent data available at the time of the study. Data are sourced from the 2011 WCPFC Yearbook excel database, ${ }^{89}$ and the Pacific Island Forum Fisheries Agency's Value of WCPO Tuna Fisheries excel database. ${ }^{90}$ It is important to note the limitations of these figures due to the inaccurate reporting of species, ${ }^{91}$ misreporting of catches by vessels, ${ }^{92}$ and the uncertainties due to the undefined western and northern boundaries of the WCPFC. Not all coastal States within the WCPFC Statistical Area currently provide tuna catch reports to the WCPFC or the Secretariat of the Pacific Community (SPC). China, Korea and Russia do not currently report any tuna catches, while Indonesia, the Philippines and Vietnam have only recently begun to develop the capacity to report tuna catches and consequently can suffer from significant uncertainties in catch data.

Fig. 2 illustrates the balance of interests for coastal States from purse seine to longline, while Fig. 3 presents the same analysis for flag States. These figures are based on the value of the tuna catch taken by their registered vessels or from waters under national jurisdiction in the benchmark year 2010. Fig. 4 illustrates the balance of interests for flag and coastal States from FAD purseseine fisheries to non-FAD purse-seine fisheries and is based on catch data prior to the introduction of FAD restrictions in 2009. Fig. 5 presents a calculation of the balance of interests between the value of the catch from a State's coastal waters and the value of the catch from that State's distant-water fishing fleet (flag State interest). Where a State has no coastal waters within the

\footnotetext{
${ }^{89}$ P Williams, Tuna Fishery Yearbook: Western and Central Pacific Fisheries Commission (Raw Excel Database) (Western and Central Pacific Fisheries Commission, Pohnpei, Federated States of Micronesia, 2011). Available at http://www.wcpfc.int.

90 P Terawasi and L Rodwell, Value of WCPO Tuna Fisheries (Excel database) (Pacific Islands Forum Fisheries Agency, Honiara, Solomon Islands, 2011).

${ }^{91}$ P Williams, Scientific Data Available to the Western and Central Pacific Fisheries Commission, Sixth Regular Session of the Scientific Committee to the Western and Central Pacific Fisheries Commission (Nuku'alofa, Tonga, 10-19 August 2009). Available at http://www.wcpfc.int.

${ }^{22}$ D Soutar, Q Hanich, M Korsten, T Jones and J McCaffrie, Safeguarding the Stocks: A Report on Analytical Projects to Support the Development of a Regional MCS Strategy for Pacific Oceanic Fisheries (Pacific Islands Forum Fisheries Agency, Honiara, Solomon Islands, 2009).
} 
Q. Hanich, Y. Ota I

The International Journal of Marine and Coastal Law 28 (2013)

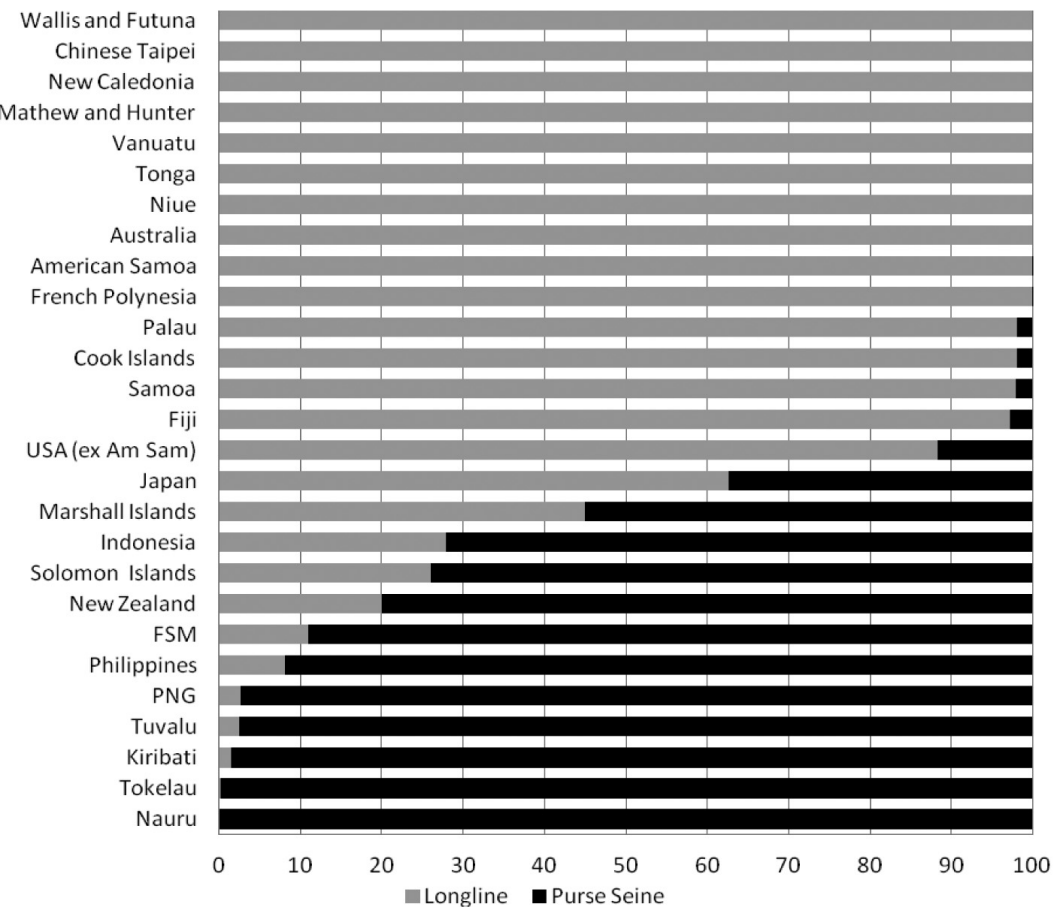

Fig. 2. Scale of coastal State interests from longline to purse seine (2010).

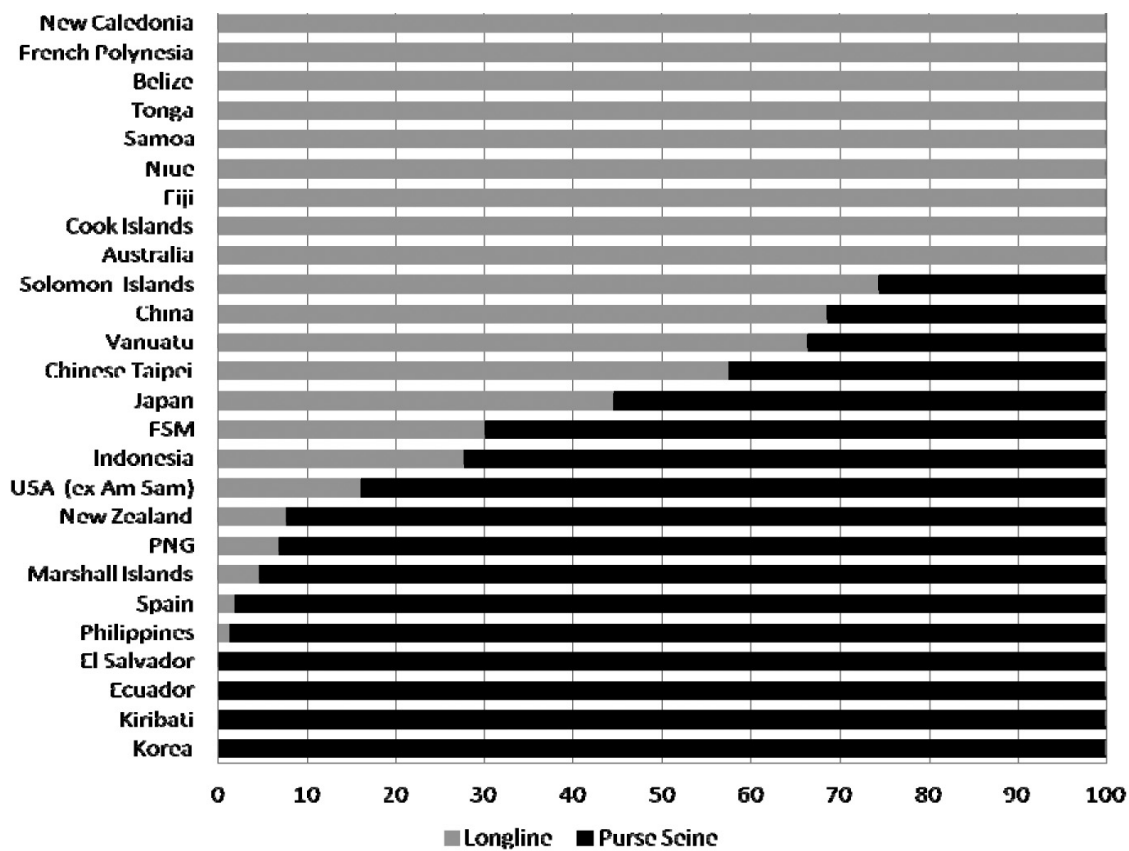

Fig. 3. Scale of flag State interests from longline to purse seine (2010). 


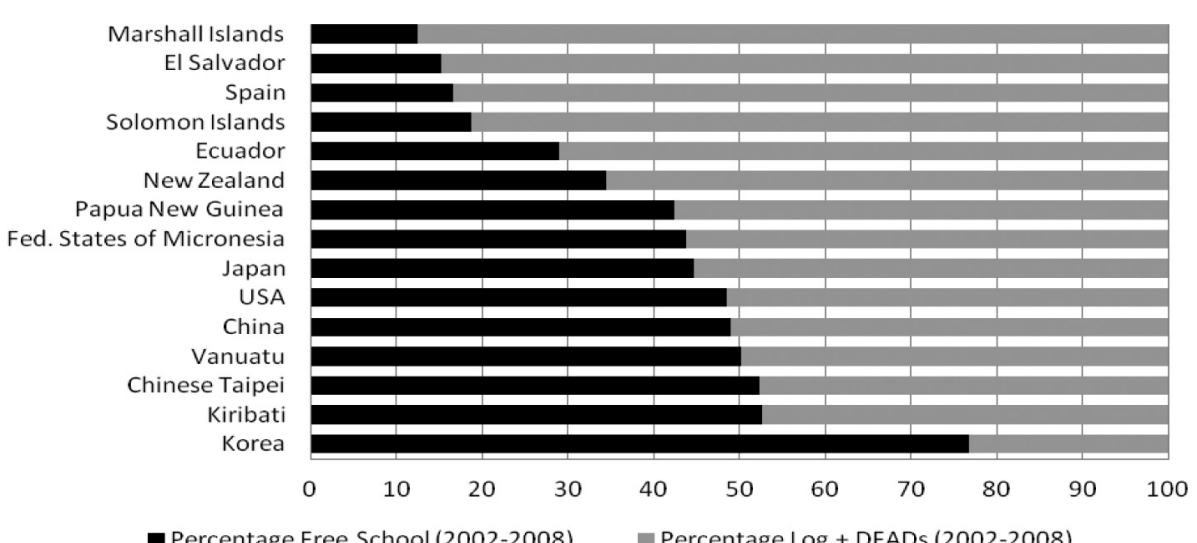

- Percentage Free School (2002-2008) — Percentage Log + DFADs (2002-2008)

Fig. 4. Scale of flag State interests in purse-seine sets on drifting FADs/logs (average 2002-2008).

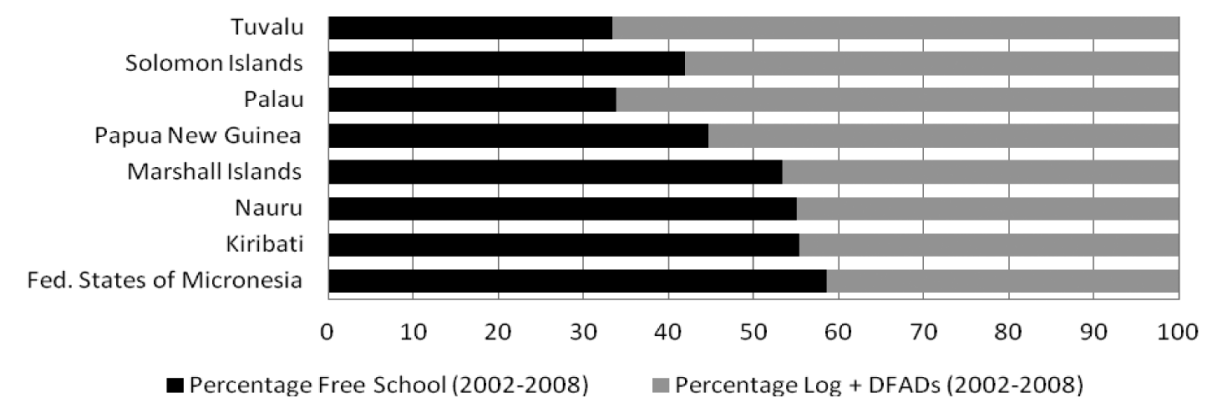

Fig. 5. Scale of coastal State interests in purse-seine sets on drifting FADs/logs (average 2002-2008).

WCPO, that State is assessed to have a $100 \%$ flag State interest. Where a State does not report any catches from registered distant-water fishing vessels, that State is assessed to have a $100 \%$ coastal State interest. ${ }^{93}$ Figs. 6 and 7 demonstrates the significance of benchmark years and illustrates the interests of States in the WCPO purse-seine and longline fisheries between 2001 and 2004, and in

93 These values include albacore, skipjack, yellowfin and bigeye to represent the various longline interests held by each State within this context. Some flag State reports include charter vessels that were registered to other States but reported under the charter State for the duration of the charter. For example, Niue did not have a registry in 2008 and depended upon a charter fleet of vessels from New Zealand and the Cook Islands. Calculations are based on data sourced from: Williams, supra note 89; Terawasi and Rodwell, supra note 90. 
Q. Hanich, Y. Ota I

The International Journal of Marine and Coastal Law 28 (2013)

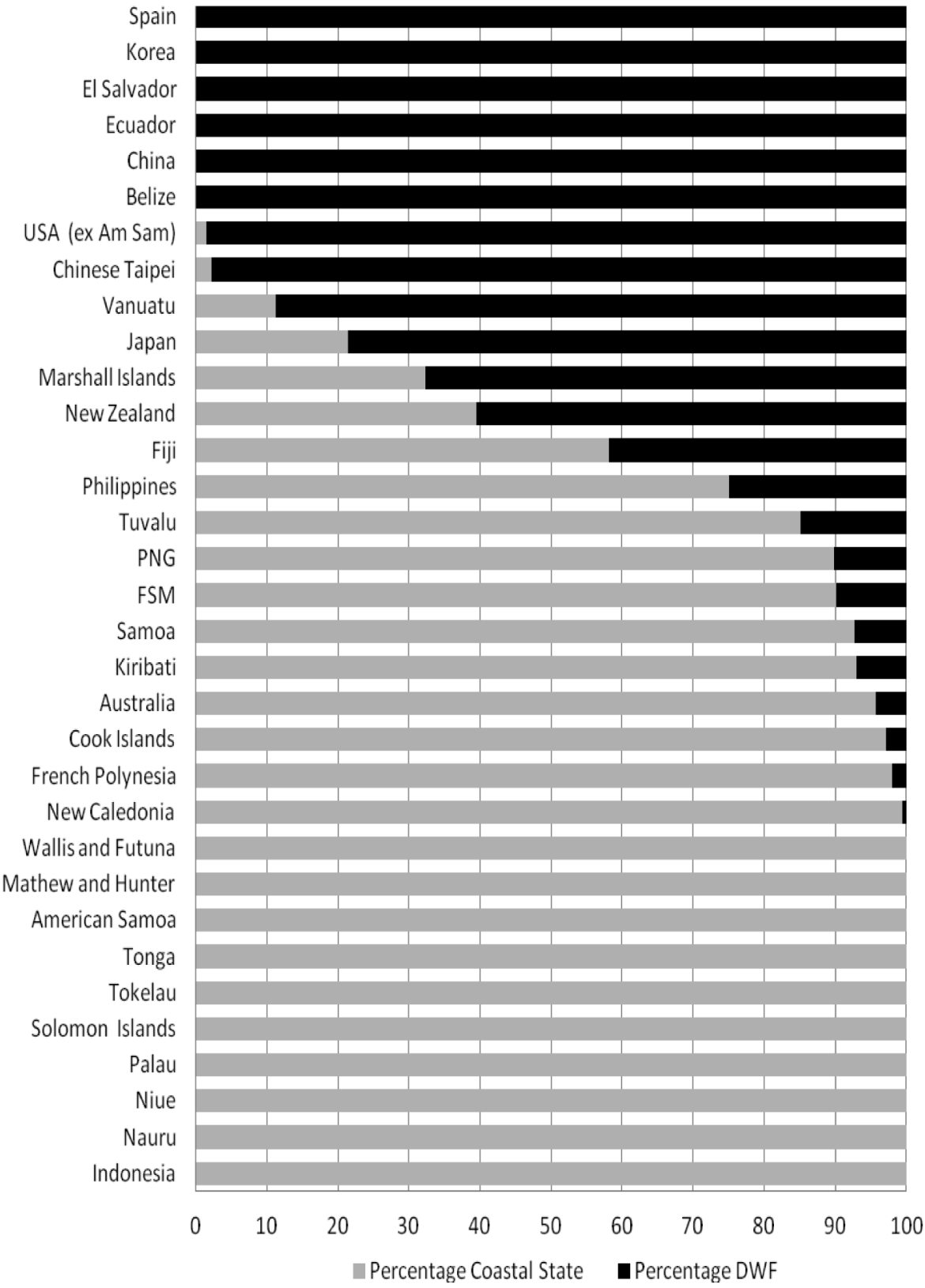

Fig. 6. Scale of interests from coastal State to flag State (2010). 
Coastal State 2001-2004
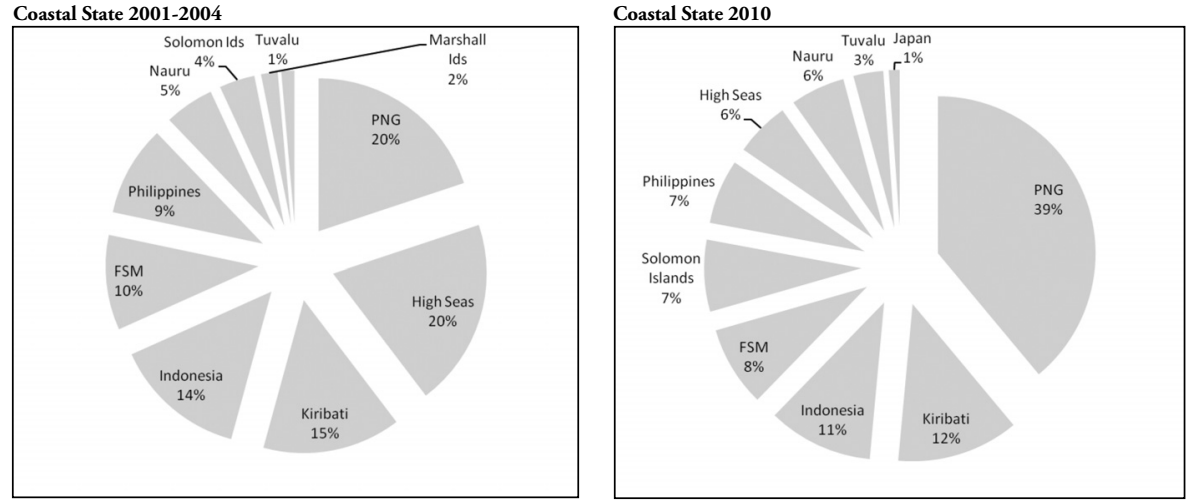

Flag State 2001-2004

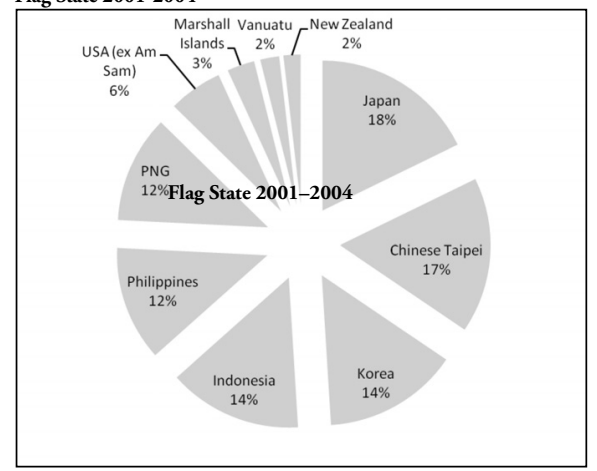

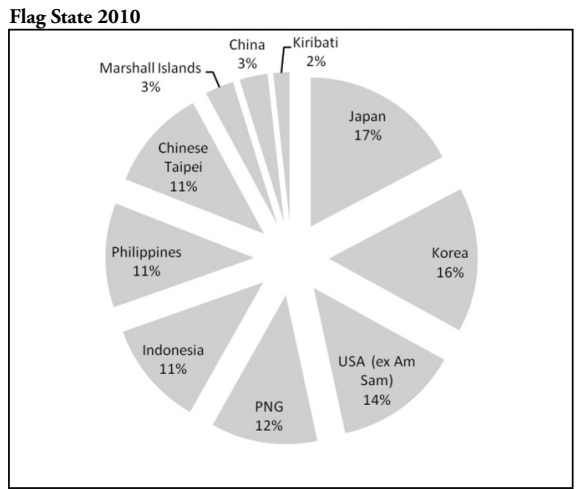

Fig. 7. Benchmark years. Value of all species caught by purse seine.

2010. These benchmark years were used in the WCPFC 2008 Conservation Measure for bigeye and yellowfin, ${ }^{94}$ and its later amended version from 2012. ${ }^{95}$ The figures show that seven of the core 14 States can be roughly identified as "purse-seine/skipjack States". Most of these States are part of the group of coastal States that dominate the most productive fishing grounds (Federated States of Micronesia, Kiribati, Nauru, Papua New Guinea, the Solomon

94 WCPFC, CMM 2008-01 Conservation and Management Measure for Bigeye and Yellowfin Tuna in the Western and Central Pacific Ocean, Fifth Regular Session of the Western and Central Pacific Fisheries Commission (Guam, 8-12 December 2008). Available at http://www .wcpfc.int.

95 WCPFC, Draft Decision on CMM2008-01, Eighth Regular Session of the Western and Central Pacific Fisheries Commission (Guam, 26-30 March 2012). Available at http://www .wcpfc.int. 
Islands and Tuvalu). Most of the benefits that these six States enjoy from the WCPO tuna fisheries come from skipjack (compared to bigeye and yellowfin), purse-seine fisheries (compared to longline and other gear types) and licensing revenue for access to their EEZ (compared to their vessel registry interests).

The seventh of these purse-seine/skipjack States is the United States. The United States is dominated by its vessel registry interests due to the significant growth of its purse-seine fleet in recent years. This fleet provides greater catches from the WCPO tuna fisheries than the predominantly longline catch from within the EEZ of its territories and Hawaii. Although far less significant in the context of its overall interest, the United States also catches substantial amounts of bigeye through its Hawaiian longline fisheries.

China, Chinese Taipei, Indonesia, Japan, Marshall Islands, the Philippines and South Korea, all have fishing interests that are more widely distributed across multiple gear types. Each of these States is a significant flag State, while Indonesia, Japan, Marshall Islands and the Philippines also have significant coastal State catches. Ecuador, El Salvador, the European Union, Marshall Islands, New Zealand, Solomon Islands, and the United States all reported that their registered purse-seine fishing vessels set on FADs more than $60 \%$ of the time and consequently are likely to have significant interests in purse-seine fisheries that set on FADs. Tuvalu similarly reported a strong interest in FADs for its EEZ. South Korean fleets on the other hand reported a far lower use of FADs.

Coastal and flag State interests are significant factors in the distribution of the conservation burden and benefit. States that are dominated by flag State or coastal State concerns are likely to suffer from conservation measures that limit fishing opportunities or impose a higher conservation burden on high seas fisheries (impact on flag States) or waters under national jurisdiction (impact on coastal States). Additionally, these States may favour measures that empower their authority and long term allocation aspirations through the implementation of limits by vessel (strengthening flag States) or zone (strengthening coastal States). ${ }^{96}$

Conservation and management measures may also have a heavy impact on developing coastal States that depend significantly on these fisheries and have

96 The WCPFC currently implements purse-seine measures through area limits (i.e., by coastal State for EEZs and by flag State for high seas) and longline measures by flag State. See CMM2008-01. Available at http://www.wcpfc.int. For further discussion of flag-based versus zone-based limits, see: V Ram Bidesi and M Tsamenyi, 'Implications of the Tuna Management Regime for Domestic Industry Development in the Pacific Island States' (2004) 28 Marine Policy 383-392. 
strong aspirations to further develop these resources. Almost all of the key coastal States in the WCPO tropical tuna fisheries are developing States. These States are ultimately responsible for managing the majority of the WCPO tropical tuna fisheries and implementing conservation and management measures. In addition to their rights and responsibilities over the fisheries within their EEZs, they have significant interests in various fishing activities and aspire to further develop their interests and benefits. Some of these States will have few other development and resource options and will be more severely affected by the conservation burden than other States with diverse resources, large institutions and substantial revenue streams from multiple economic activities.

To date, these developing coastal States have successfully sought exemptions for their developing fisheries from most conservation and management measures. While this satisfies short-term concerns, there is increasing recognition that these exemptions are significantly undermining the effectiveness of conservation and management measures. ${ }^{97}$ The interests of these developing coastal States would need to be substantially addressed and valued in a methodology for distributing the conservation burden and benefit, if these exemptions were to be removed.

Many of these same States are also home to coastal communities that depend heavily upon living marine resources for food security and employment in artisanal fisheries. In the Pacific islands, the tuna fisheries can represent an important source of protein and livelihoods. ${ }^{98}$ Similarly, coastal communities in Indonesia, the Philippines and Vietnam also depend heavily

97 In 2009, John Hampton presented a SPC study that found that all exemptions were having a significant impact on the effectiveness of the 2008 Conservation and Management Measure for Bigeye and Yellowfin. See: J Hampton and S Harley, Assessment of the Potential Implications of Application of CMM-2008-01 for Bigeye and Yellowfin Tuna, Fifth Regular Session of the Scientific Committee to the Western and Central Pacific Fisheries Commission (Port Vila, Vanuatu. 10-21 August, 2009). Available at http://www.wcpfc.int. In the long term, Pacific island States appear to accept that these broad exemptions will need to be replaced with specific measures. H Parris, 'Tuna Dreams and Tuna Realities: Defining the term 'maximising economic returns from the tuna fisheries' in six Pacific island States' (2010) 34 Marine Policy 105-113.

98 Scientists have recommended that Pacific island governments should increase local access to these tuna fisheries in order to partly meet increasing Pacific island food security requirements. Recent studies have estimated that $75 \%$ of Pacific island coastal fisheries will not meet forecast food security needs due to a forecast $50 \%$ growth in population by 2030 , limited productivity of coastal fisheries (exacerbated by overfishing) and inadequate national distribution networks. J Bell, M Kronen, A Vunisea, W Nash, G Keeble, A Demmke, S Pontifex and S Andreafouet, 'Planning the Use of Fish for Food Security in the Pacific' (2009) 33 Marine Policy 64-76. 
on living marine resources for food security and livelihoods. ${ }^{99}$ The following coastal States are home to coastal communities that depend upon WCPO tuna fisheries for food security and artisanal employment to some degree: American Samoa, Cook Islands, Fiji, French Polynesia, Indonesia, Japan, Kiribati, Marshall Islands, Palau, Papua New Guinea, Philippines, Nauru, New Caledonia, Niue Samoa, Solomon Islands, Tokelau, Tonga, Tuvalu, USA Territories and Vanuatu. ${ }^{100}$ Many of the subsistence and artisanal fisheries that operate in these States and territories catch significant proportions of tuna. ${ }^{101}$ Given their food security interests, these coastal States will suffer from conservation measures that limit artisanal catches or inequitably transfer any conservation burden onto artisanal communities. ${ }^{102}$

The distribution of the conservation burden and benefit could also extend to other industries and markets. A number of States around the world, including many of the core 14, have a commercial market interest in the WCPO tropical tuna fisheries through their consumption of tuna products. Tropical tuna are processed into a variety of products, ranging from minimally processed fresh and frozen whole tuna (i.e., bigeye and yellowfin), through various loining stages to fully processed canned retail products (i.e. skipjack and yellowfin). Canned tuna is one of the most significant products that originate from the WCPO purse-seine fisheries.

Thailand is the world's largest processor of canned tuna. Thailand is also the recipient of almost half of the WCPO's purse-seine catch. ${ }^{103}$ American Samoa, China, Indonesia, Japan, Korea, the Philippines, and Papua New Guinea and the USA also have significant interests in domestic processing operations that are highly dependent upon consistent supplies of skipjack and yellowfin.

\footnotetext{
${ }^{99}$ N Salayo, L Garces, M Pido, K Viswanathan, R Pomeroy, M Ahmed, I Siason, K Seng and A Masae, 'Managing Excess Capacity in Small-Scale Fisheries: Perspectives from Stakeholders in Three Southeast Asian Countries' (2008) 32 Marine Policy 692-700.

${ }^{100}$ Q Hanich, 'Interest and Influence-Conservation and Management in the Western and Central Pacific Fisheries Commission' (Ph.D. Thesis, University of Wollongong, 2011).

101 R Gillett, M McCoy, L Rodwell and J Tamata, Tuna: A Key Economic Resource in the Pacific Islands (Asian Development Bank and Forum Fisheries Agency, Honiara, Solomon Islands, 2001).

102 While there has been no discussion within the WCPFC of limiting artisanal catches, it is noteworthy that the European Union delegate to the Kobe II International Workshop on RFMO Management of Tuna Fisheries suggested that the Indian Ocean Tuna Commission may need to consider limiting artisanal catches of tuna, given their impact on Indian Ocean tuna stocks. Personal notes. Comments by Mr Antonio Fernandez. European Commission Delegate. Comments made on 30 June 2010 at Kobe II International Workshop on RFMO Management of Tuna Fisheries. Brisbane, Australia. 29 June-1 July 2010.

103 Trimarine, Tuna Markets and Seiner Capacity. RFMO Tuna Management Workshop (Brisbane, Australia, 2010).
} 
Consequently each of these States has a strong interest in the continued operation of the skipjack and yellowfin fisheries and their provision of cheap raw material for their factories. Some WCPO States and territories also export various fresh, smoked and frozen products to global markets. Much of this requires minimal processing infrastructure compared to canning and loining, although some operations, such as katsuoboshi, require significant processing infrastructure. The interests within these States may suffer if conservation measures were to restrict supply seasonally (as could happen if the WCPFC were to adopt proposals to close the entire WCPO purse-seine fishery for 3 months a year). ${ }^{104}$ Similarly, these States would suffer if the WCPFC failed to address sustainability concerns.

The largest consumer markets in the world for fresh, frozen, smoked and canned tuna are the USA, Japan and Europe ${ }^{105}$ All of these markets, to some degree, depend upon the WCPO tropical tuna fisheries for their supply. In addition, markets in developing States are looking towards domestically produced and imported canned tuna to counter food insecurity and as a cheap form of protein. ${ }^{106}$ Within this context, conservation and management decisions within the WCPFC, particularly in regard to skipjack and purse-seine fisheries, can quickly affect coastal food security and have significant repercussions for local and global markets. ${ }^{107}$

\section{Assessing Management Options and Distributing the Conservation Burden and Benefit}

Within this complicated mix of interests, the WCPFC and its members must develop, negotiate and implement a conservation and management measure that includes a package of management options that will collectively achieve the conservation goal. The WCPFC can utilise a number of management options to meet these requirements. However, each of these management options will also directly and indirectly affect the areas of interest of the WCPFC members to varying degrees.

\footnotetext{
${ }^{104}$ For example, in February 2011 an industry association that represents some tuna industry interests called for a three-month closure of the WCPO purse-seine fishery. International Seafood Sustainability Foundation (ISSF), Tuna Coalition Backs Seasonal Pacific Fishery Closure, ISSF. Available at: http://iss-foundation.org/2011/02/22/tuna-coalition-backs-seasonalpacific-fishery-closure/. Accessed on 23 February 2011.

${ }_{105}$ C Catarsi, World Tuna Markets (FAO, Rome, Italy 2004).

106 Ibid.

107 Y Jeon, C Reid and D Squires, 'Is There a Global Market for Tuna? Policy Implications for Tropical Tuna Fisheries' (2008) 39 Ocean Development and International Law 32-50.
} 
In order to implement a new approach to distributing the conservation burden and benefit, we propose that the WCPFC develop a methodology based on four areas of interest (coastal State, flag State, market/consumer State, and developing State) and determine values for each interest field. The WCPFC would then adopt a 'Burden-Sharing Conservation Measure' that prescribes the decision-making framework for progressing through this methodology and distributing any conservation burden and benefit. Fig. 8 illustrates how such an approach might work in practice through a decision tree that charts each step in the process.

Subsequently, if a concern with overfishing arises, then the WCPFC Scientific Committee would have a clear mandate to advise on the necessary conservation response to address overfishing concerns and on the conservation measure options that would achieve this conservation response and their necessary extent (i.e., restrictions or prohibitions on certain gear types, areal or seasonal closures, capacity limits, catch/effort limits). The WCPFC has not yet agreed on reference points, so in its absence, the conservation response must be consistent with the WCPF Convention. This requires that the conservation and management measure:

a. be based on the best scientific evidence available;

b. ensure the long-term conservation and sustainable use of the WCPO tuna fisheries and their optimum utilisation;

c. maintain or restore stocks at levels capable of producing maximum sustainable yield, as qualified by relevant environmental and economic factors;

d. adopt a precautionary approach;

e. avoid adverse impacts on the marine environment and maintain the integrity of marine ecosystems;

f. ensure that conservation and management measures do not result in transferring a disproportionate burden of conservation action onto developing State parties and territories.

In this example, the WCPFC Scientific Committee would advise that in order to maintain or restore stocks at levels capable of producing maximum sustainable yield, the WCPFC adopt a measure that: ${ }^{108}$

108 WCPFC, Report of the Seventh Regular Session of the Scientific Committee of the Western and Central Pacific Fisheries Commission (Western and Central Pacific Fisheries Commission, Pohnpei, Federated States of Micronesia, 9-17 August 2011). Available at http://www.wcpfc int. 


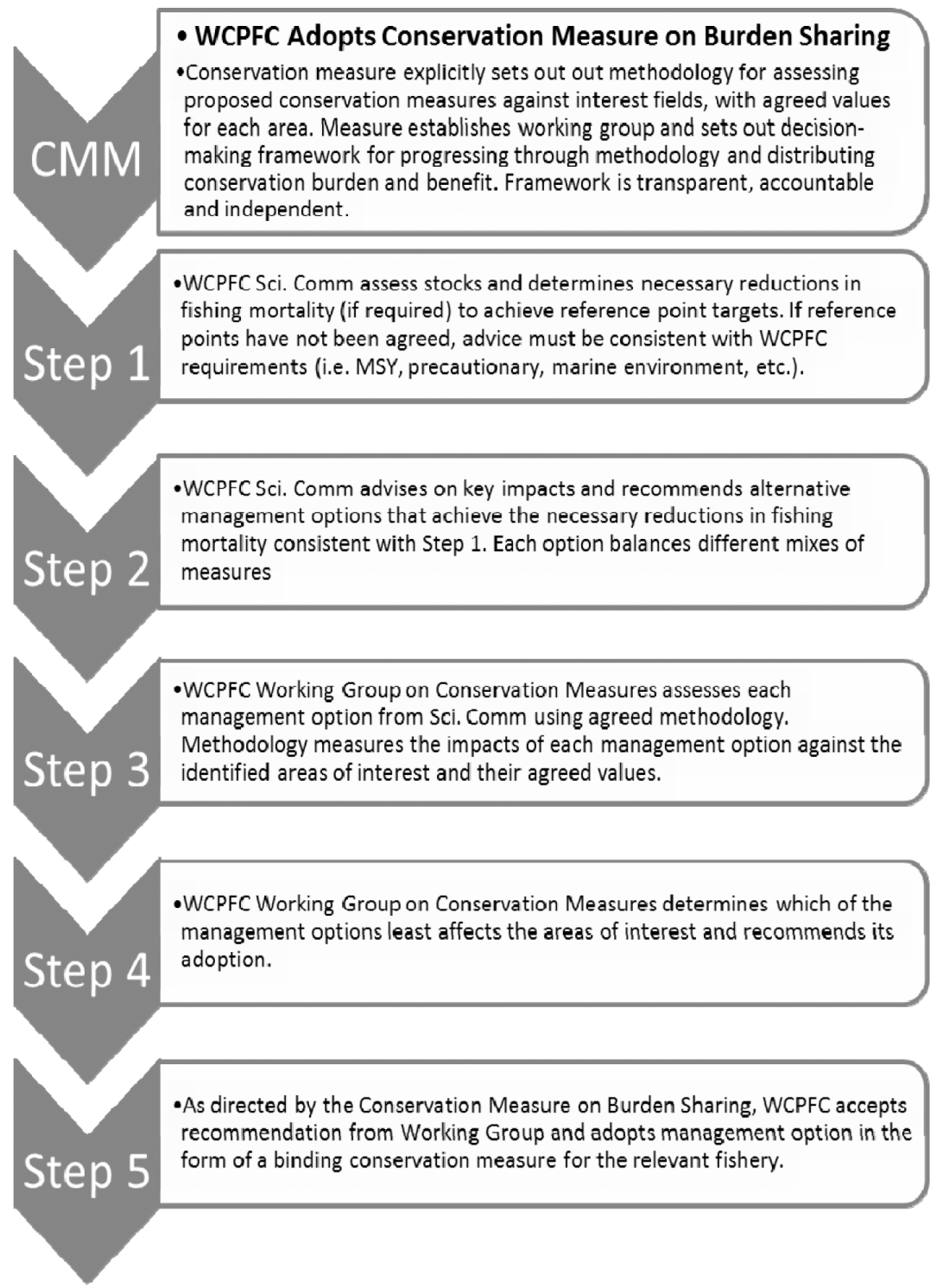

Fig. 8. A decision tree for distributing the conservation burden and benefit.

a. reduces fishing mortality for bigeye by a minimum of 39\% from 2004 levels, or $28 \%$ from average 2001-04 levels, or 32\% from average 200609 levels;

b. reduces fishing mortality of juvenile bigeye in order to increase potential yield and optimise utilisation;

c. ensures no increase in fishing mortality for yellowfin in the western equatorial region; 
d. reduces fishing mortality of juvenile yellowfin in order to increase potential yield and optimise utilisation;

e. implements precautionary limits on fishing activities for skipjack.

The WCPFC Scientific Committee would then advise on the key impacts and recommend alternative management options that balance different mixes of measures that limit longline catches of bigeye, restrict purse-seine fishing activities, limit pole-and-line catches of yellowfin in the Japanese region, and limit catches of bigeye and yellowfin within the Indonesian and Philippine fisheries. The Scientific Committee would be required to limit its proposed management options to only those that achieve the conservation targets for producing the maximum sustainable yield (until a harvest strategy is adopted that establishes agreed reference points).

The approach would then measure the impact of these alternative management options against the four areas of interest and their agreed values. When measuring the management options against the areas of interest, the approach might consider the following impacts on these areas and their pre-agreed values:

- Seasonal closures: Some WCPFC members have supported the introduction of seasonal closures on the purse-seine fishery in order to reduce fishing effort, and therefore reduce fishing mortality of bigeye, yellowfin and skipjack. The efficacy of this measure depends upon the degree to which the restriction truly removes the effort from the fishery. It is likely that fleets will respond through maximising non-fishing days (i.e., maintenance, transits, etc.) during seasonal closures in order to minimise reductions in fishing effort. Similarly, some fleets may attempt to transfer their fishing effort to other fisheries during seasonal closures. The application of a seasonal closure is likely to significantly affect those coastal States and processing interests that have few options to mitigate the impact of seasonal closures, thereby raising concerns that such measures may disproportionately affect developing coastal State Parties.

- Some WCPFC members have supported the introduction of area closures to reduce fishing effort and thereby reduce fishing mortality of bigeye, yellowfin and skipjack. As with seasonal closures, the efficacy of this measure depends upon the degree to which the restriction truly removes the effort from the fishery. It is likely that fleets will respond by migrating to other fishing zones such as EEZs, archipelagic waters and other high seas. The application of an area closure is likely to have most impact on hosting coastal States if the area occurs within an EEZ, or distant-water fishing States most if the measure closes areas of high seas. 
The use of high seas closures in a mix of measures offers opportunities for the WCPFC to comply with the WCPF Convention's Article 30 and avoid disproportionate transfers of conservation burden onto developing coastal States.

- The WCPFC currently prescribes a three-month prohibition on the use of FADs by the purse-seine fishery. Recent assessments have indicated that this has been highly successful at reducing bigeye fishing mortality and has a strong impact on bigeye conservation. Assessments have also suggested that reductions in catches during the FAD closure may be offset by the larger average size of fish caught. ${ }^{109}$ Further restrictions and limitations on the numbers of FADs that can be set are likely to affect most members less than a total purse-seine closure, with minimal difference in conservation outcome. However, a FAD closure will significantly affect some fleets that have historically used FADs more than others, and also some coastal States where the use of FADs is higher than elsewhere. Other gear restrictions are also feasible, including restrictions on purseseine mesh size, time restrictions on deployment or retrieval, types of hooks, etc.

- Some WCPFC members have strongly argued for the implementation of capacity limits to reduce effort, thereby reducing fishing mortality and increasing profitability. Various studies have also suggested that the profitability of the WCPO tuna fisheries could be increased through significant changes in fleet composition and reductions in most, if not all, fleets. ${ }^{110}$ Catches of bigeye and yellowfin by purse-seine fishing vessels, particularly juveniles in schools associated with FADs, provide a smaller benefit to the overall value of the WCPO tuna fisheries than would be achieved if these fish had been allowed to mature and then be caught by

\footnotetext{
109 J Hampton and P Williams, Analysis of Purse Seine Set Type Behaviour in 2009 and 2010, Seventh Regular Session of the Scientific Committee of the Western and Central Pacific Fisheries Commission (Pohnpei, Federated States of Micronesia, 9-17 August 2011). Available at http://www.wcpfc.int.

${ }_{110}$ M Bertignac, A Hand, J Hampton and H Campbell, A Bioeconomic Model of Longline, Pole and Line and Purse Seine Fisheries in the Western and Central Pacific (ACIAR, Canberra, Australia, 1998); H Campbell, 'Managing Tuna Fisheries: A New Strategy for the Western and Central Pacific Ocean' (2000) 24(2) Marine Policy 159-163; M Bertignac, H Campbell, J Hampton and H Campbell, 'Maximising Resource Rent from the Western and Central Pacific Tuna Fisheries' (2000) 15 Marine Resource Economics 155-177; T Kompass and N C Tuong, 'Economic Profit and Optimal Effort in the Western and Central Pacific Tuna Fisheries' (2006) 21(3) Pacific Economic Bulletin 46-62; R Hannesson and J Kennedy, 'RentMaximisation Versus Competition in the Western and Central Pacific Tuna Fishery' (2009) 1(1) Journal of Natural Resources Policy Research 49-65.
} 
longline. If purse-seine FAD sets were prohibited, then these fish may potentially become available to the longline fishery for a far greater benefit to the overall value of the WCPO tuna fisheries. However, bioeconomic modelling has found that the benefits from significant fleet restructuring and purse-seine reductions would be enjoyed disproportionately with detrimental impacts on coastal States with significant purse-seine fisheries. ${ }^{111}$ Capacity limits can also be undermined by effort creep, where vessels become faster, larger, more powerful and more effective at catching fish, thereby effectively increasing capacity. In addition, some members have strongly opposed capacity limits due to concerns that this would limit development opportunities for developing coastal States and impose a disproportionate conservation burden on developing State Parties. Such reductions in capacity could limit demand for access and potentially negatively affect coastal State access revenue. Consequently, any resolution of issues related to overcapacity and fleet structures will likely require some mechanism to equitably distribute the reductions and benefits.

- The WCPFC currently prescribes catch limits on the longline fishery for bigeye and yellowfin and effort limits on the purse-seine fishery. These two management options provide a relatively transparent management mechanism for directly limiting fishing mortality. The efficacy of these management options depends on the consistency of the catch and effort limits with the scientific advice, and the monitoring of their implementation so as to avoid misreporting and discards. Any exemptions or special conditions must be considered during the formulation of the measure to ensure that these do not inflate the total catch or effort beyond the recommended fishing mortality. The allocation of catch limits to national fleets and effort limits to specific areas has avoided some of the problems inherent with "Olympic" limits, that motivate a race to fish, but further discussion is likely to be required to more fully allocate catches and effort for high seas fisheries. Such discussions can quickly become contentious given the lack of an agreed framework for the allocation of such limits, and the need to ensure that any allocation of limits

\footnotetext{
111 C Reid, M Bertignac and J Hampton, Further Development of, and Analysis Using, the Western and Central Pacific Ocean Bioeconomic Tuna Model (WCPOBTM) (FFA and SPC, Honiara, Solomon Islands 2006); C Reid, Economic Implications of an Implicit Allocation of Bigeye Harvest Rights Through an Across the Board Reduction in Effort Levels in the Western and Central Pacific Tuna Fishery, FAO Sharing the Fish Conference. Perth, Australia. February 27-March 2, 2006. Accessed online July 2012 at: http://www.fishallocation.com/papers/pdf/presentations/PresentChristopherReid.pdf.
} 
does not result in a disproportionate burden of conservation action on developing State parties and territories. Other feasible effort limits can include further restrictions on transhipments at sea to reduce opportunities to continuously maintain fishing effort without interruption.

The methodology used to measure these impacts would then determine which of the alternate management options affected the areas of interest and values the least. The decision-making framework prescribed in the Burden-Sharing Conservation Measure would then prescribe that the management option with the minimal impact on the areas of interest and values be adopted.

\section{Conclusion}

This article recommends that RFMOs consider developing a new approach to the distribution of the conservation burden and benefit that separates political and equity arguments from fisheries science and better enables RFMOs to meet their conservation and equity obligations. The article recommends that RFMOs consider adopting conservation measures that prescribe such approaches and include methodologies for determining the scope of a conservation measure and its impact on members.

Such an approach would enable RFMOs to expand on existing conservation and management processes to include this new 'conservation burden' step. This would be more relevant to the current context of declining fish stocks, as opposed to attempts to implement approaches to rights-based management that typically focus on dividing the "pie" (while in reality the pie is shrinking). This approach would also provide a greater degree of flexibility than existing models of rights-based management, and would avoid coastal State arguments that oppose RFMOs implementing rights-based management frameworks over waters under their national jurisdiction. In this regard, the approach could be more likely to resolve "vested-interest" political obstacles to the adoption of sufficiently strong conservation measures than existing concepts of rights-based management. 